\title{
PRELIMINARY STUDIES ON MILLIPEDE: PROXIMATE COMPOSITION, NUTRITIONALLY VALUABLE MINERALS AND PHYTATE CONTENTS.
}

\author{
(Recieved 5 April 2002; Revision accepted 3 June 2003)
}

\begin{abstract}
The nutritive potential of millipede was evaluated with respect to its proximate composition, energy value, mineral and phytate contents. It contained $24.85 \mathrm{~g} / 100 \mathrm{~g}$ DM crude protein, crude fibre $4.88 \mathrm{~g} / 100 \mathrm{~g}$ DM while ash was $2.23 \mathrm{~g} / 100 \mathrm{~g}$ DM. The sample had low level of fat $(5.20 / 100 \mathrm{~g} \mathrm{DM})$. The energy level was $397.56 \mathrm{Kcal}$. The concentration of Ca, $\mathrm{K}, \mathrm{Mg}, \mathrm{Na}, \mathrm{Cl}$ and $\mathrm{l}$ were found to be high whereas Zn, Fe and Mn were low. The levels of phytate and phytate phosphorus were generally high and the sample had more than $80 \%$ of its total phosphorus linked to phytate. The phytate: Zn molar ratio of the sample was relatively low, indicating excellent Zn bioavailability. Based on the results, it is suggested that nutritional potentials of millipede should be harnessed.
\end{abstract}

KEYWORDS: Millipede, proximate composition, minerals, phytate, bioavailability.

\section{INTRODUCTION}

Millipede belongs to the class Diplopoda. They have between 11 to 100 trunk segments. They are world wide in distribution and are nearly always found in or under leaf litter, humus, or decaying logs. Their many legs help bull dose through the habitat. They feed on decaying plant matters and few, suck plant juices (Miller and Harley, 1996).

Nutrition is perhaps the most important consideration in livestock management, supplying feed in adequate amount or feeding poor quality feeds are responsible for the low livestock production in the tropics. The quest for least-cost dietary formulation, especially in non-ruminant feeding, has involved the replacement of the more expensive conventional feeding stuff with cheaper alternatives. Agbede and Aletor, (1997) have partially or wholly replaced conventional protein resources such as fish meal, groundnut cake and Soya-bean cake (ingredient with high import content) with cheaper alternative protein resources such as blood meal, cotton seed cake, palm kernel cake, brewer's yeast etc. with varying degrees of success.

Detailed information on the nutritional values of millipede is yet to be documented. The main objective of this work therefore, is to investigate the proximate composition, mineral and phytate contents. This study is important to establish the nutritional values of millipede with a view to ascertain its nutritional potentials in livestock production.

\section{MATERIALSAND METHODS}

\section{Sampling}

The millipede sample was collected at the Federal College of Agriculture, Akure, Ondo state campus. $250 \mathrm{~g}$ of the sample was washed in distilled water, oven dried at $550 \mathrm{C}$ for $6 \mathrm{~h}$; then finely ground, sieved (1 $\mathrm{mm}$ sieve) and mixed thoroughly. After mixing, the sample lots were quartered and sampling for analyses was carried out by the procedure described by Pearson (1976).

\section{METHODS}

Sample was analysed for proximate composition using the AOAC (1990) procedures, carbohydrate was determined by difference. Total energy was calculated according to the following equations (Manzi et al., 2001).

Energy $(\mathrm{Kcal})=4 \times($ g protein $+\mathrm{g}$ carbohydrate $)+9 \times(\mathrm{g} f \mathrm{t})$.

Phosphorus was determined using a Spectronic 20 colorimeter by the phosphovanadomolybdate method (AOAC, 1990). Phytate phosphorus (P) and phytate were determined using the methods of Young and Greaves (1940) as modified by Oduguwa et al., (1998). Phytate P as\% total P and phytate: $Z n$ were calculated using the methods of Abulude (2001).

Minerals were analysed using the solution obtained by dry ashing the sample and dissolving it in 10\% hydrochloric acid and making up to $100 \mathrm{~cm} 3$. Ca, Mg, $\mathrm{Zn}$, Fe, Mn were determined with a Buck atomic absorption spectrophotometer (AAS: Model SP9). Na and $K$ were measured with a Corning 405 flame photometer (AOAC, 1990). Chloride and iodide were determined using the methods in Vogel (1989). All chemicals were BDH analytical grade. Data collected were subjected to statistical analysis including analysis of variance. 
Table 1: Proximate Composition (g/100gDM ) of Millipede

\begin{tabular}{l|l|l|l} 
Parameter & Mean & SD & CV $(\%)^{\mathrm{c}}$ \\
& & & \\
& & & \\
Moisture & & & \\
Carbohydrate (by & 10.26 & 0.51 & 4.01 \\
difference) & & & \\
Crude protein & 24.85 & 0.25 & 0.40 \\
Crude fat & 5.20 & 0.42 & 1.69 \\
Crude fibre & 4.88 & 0.35 & 6.73 \\
Ash & 2.23 & 0.52 & 9.02 \\
Energy & 397.56 & 2.34 & 23.32 \\
& & 2.14 & \\
& & &
\end{tabular}

"DM Dry matter "SD - Standard Deviation ' CV (\%) Coefficient of variation (percent)

Table 2: Mineral Composition $\left(\mathrm{Mg} / 100 \mathrm{~g} \mathrm{DM}^{\mathrm{a}}\right)$ of Millipede

\begin{tabular}{llll} 
Parameter & Mean & $\mathrm{SD}^{6}$ & $\mathrm{CV}(\%)^{\mathrm{C}}$ \\
$\mathrm{Na}$ & 214.21 & 4.08 & 2.14 \\
$\mathrm{~K}$ & 1752.05 & 28.05 & 1.60 \\
$\mathrm{Ca}$ & 3703.60 & 31.60 & 8.53 \\
$\mathrm{Mg}$ & 873.33 & 2.89 & 0.33 \\
$\mathrm{Zn}$ & 4.30 & 0.20 & 4.65 \\
$\mathrm{Fe}$ & 5.20 & 0.35 & 6.75 \\
$\mathrm{Mn}$ & 1.20 & 0.21 & 17.35 \\
$\mathrm{Cl}$ & 1251.01 & 2.08 & 0.17 \\
$\mathrm{I}$ & 780.25 & 1.98 & 0.25 \\
$\mathrm{Ratios}$ & & & \\
$\mathrm{K} / \mathrm{Mg}$ & 2.01 & 0.10 & 4.73 \\
$\mathrm{~K} / \mathrm{Ca}$ & 0.48 & 0.04 & 7.89 \\
$\mathrm{Mg} / \mathrm{Ca}$ & 0.24 & 0.01 & 4.00 \\
$\mathrm{Na} / \mathrm{K}$ & 0.12 & 0.02 & 11.46 \\
\hline
\end{tabular}

a, b, c see footnote Table 1.

\section{RESULTS AND DISCUSSION}

Table 1 shows the proximate composition of the sample in $\mathrm{g} / 100 \mathrm{~g}$ edible portion. This result shows the chemical composition as $\mathrm{g} / 100 \mathrm{~g} \mathrm{DM}$ and also the energy in Kcal. From the Table, it can be deduced that this sample is low in moisture content. This content is $10.26 \mathrm{~g} / 100 \mathrm{~g} \mathrm{DM}$ with coefficient of variation in percent $(\mathrm{CV} \%)$ of 4.01 . The result is in close agreement with that reported for variegated grasshopper (13.5/100g: Olaofe et al; 1998). The observed low moisture level favours the keeping quality of the sample.

In terms of the protein level $(22.85 \mathrm{~g} / 100 \mathrm{DM})$, the sample can be considered as a good source of protein. The protein content is in close agreement with results obtained by Aduku (1993) for grasshoppers (26.8\%) and termites raw $(20.4 \%)$. The sample is low in crude fat $(5.20 \mathrm{~g} / 100 \mathrm{~g})$ crude fibre $(4.88 \mathrm{~g} / 100 \mathrm{~g})$ and ash $(2.23 \mathrm{~g} / 100 \mathrm{~g})$. Results of the proximate composition of the sample indicate the potentials for its use as source of good quality feed in livestock production. This millipede cannot be considered as rich sources of fat and fibre. The total carbohydrate is high making it a very good source of this nutrient. This sample is a good energy source and the energy is derived mainly from carbohydrate. The energy provided by the sample is shown in Table 1.

The mineral composition is shown in Table 2 and shown in $\mathrm{mg} / 100 \mathrm{~g}$ DM edible portion. The sodium content (214.21 mg/100g) is higher than those reported for grasshopper, $36.0 \mathrm{mg} / 100 \mathrm{~g}$ (Olaofe et al., 1998; grasshopper, 40mg/100g Aduku, 1993); edible fish, $12.563 .1 \mathrm{mg} / 100 \mathrm{~g}$ (Adeyeye, 1996), but lower than that reported for prawns, $88 \mathrm{mg} / \mathrm{g}$ (Adeyeye, 2000). The potassium content is higher than result recorded for prawns (Adeyeye, 2000). The calcium content $(3703.60 \mathrm{mg} / 100 \mathrm{~g}$ ) surpasses those reported for grasshoppers, 40mg/100g (Aduku, 19993), rain termite and prawns, $7300 \mathrm{mg} / \mathrm{g}$ (Adeyeye, 2000). The values of some of the trace minerals in the millipede sample as reported here are (mg/100g): $Z n(4.30) ; \mathrm{Fe}(5.20)$ and $M n(1.20)$. The values of these minerals in literature as reported by Olaofe et al., (1988) and Adeyeye, (2000) for grasshopper and prawns respectively are lower than the current results. The levels of trace minerals may not be of concern in terms of toxicity to livestock animals. They are below the upper limit of safe intake of 2 to $5 \mathrm{mg} /$ day $(\mathrm{Mn}), 12$ to $15 \mathrm{mg} /$ day $(\mathrm{Zn})$ and 10 to $15 \mathrm{mg} /$ day $(\mathrm{Fe})$. lodine content of this sample is $780.25 \mathrm{mg} / 100 \mathrm{~g}$. The result compares favourably with fish (750mg/100g), but higher than those reported for meat (240mg/100g) and milk (230mg/100g) (Wenlock et al., 1981). The value obtained in this work is ideal for feeding laying hens because high levels of iodine have indicated that production of the hormone was not impaired (Marcilese et al., 1987). The major role of iodine in nutrition arises from the importance of thyroid hormones in the growth and developments of humans and animals (Hetzel and Dunn, 1989). Chlorine content is high. The combination of this with sodium is good for the animal because sodium chloride is meant to maintain the water balance of the body, also the osmotic balance in cell. Excess is lost iri the urine of animals (Roberts et al., 1996 and Tull, 1990).

The conceti.: ratios of $\mathrm{K} / \mathrm{Mg}, \mathrm{K} / \mathrm{Ca}, \mathrm{Mg} / \mathrm{Ca}$ and $\mathrm{Na} / \mathrm{K}$ are shown in Table 2. All the ratios $c^{\prime}$ 'w a low variability. The interpretation of these low var ties is that animals consuming this millipede sample are taking in more potassium, magnesium and sodium than other minerals from this source.

Phytate, phosphorus (P) and calculate phytate: $Z n$ of the 
sample are shown in Table 3. Total $P$ has a mean value of $183.40 \mathrm{mg} / 100 \mathrm{~g} \mathrm{DM}$. The level reported is in total agreement with results recorded for vegetables (Abulude, 2001), but higher than that reported for some varieties of mushroom (Abulude et al., 2001). Phytate P and phytate levels are $154.32 \mathrm{mg} / 100 \mathrm{~g}$ and $549.38 \mathrm{mg} / 100 \mathrm{~g}$ respectively. The level observed are in the same range reported for cereals and legumes (Reddy et al., 1982) and lupin seeds (Trugo et al., 1993). This sample may be the choice when considering feeds with low phytate content for livestock. The phytate $P$ as \% total $P$ represents the percentage of the total $P$ present in the sample. The ratio of phytate: $\mathrm{Zn}$ is 12.00 .

Table 3: Phosphorus, Phytate and Calculated phytate: Zn molar ratio of Millipede.

\begin{tabular}{lrrr} 
Parameter & Mean & \multicolumn{1}{l}{ SD } & CV $(\%)$ \\
& & & \\
& & & \\
& & $\ldots$ & $\ldots$ \\
Total Phosphorus $(\mathrm{mg} / 100 \mathrm{~g})$ & 183.40 & 2.50 & 1.36 \\
Phytate Phosphorus $(\mathrm{mg} / 100 \mathrm{~g})$ & 154.32 & 3.47 & 2.25 \\
Phytate $(\mathrm{mg} / 100 \mathrm{~g})$ & 549.39 & 1.74 & 0.32 \\
Phytate Phosphorus as & & & \\
\% total Phosphrous & 84.14 & 0.23 & 0.04 \\
Phytate: Zn & 12.00 & 0.15 & 1.27
\end{tabular}

Phytate may reduce the intestinal absorption of $\mathrm{Mg}, \mathrm{Ca}$, $\mathrm{Zn}$ and $\mathrm{Fe}$ by forming insolubie compounds in the conditions of the intestinal tract, but the result observed in this report may not have any serious adverse effects on the animals that feed on them. Phytate content is not considered to be absolute and may vary depending upon the variety, climatic conditions, locations, type of soil and the year during which they are found. Phytate: mineral ratio rather than absolute phytate levels are limiting in terms of mineral bioavailability. Foods with a molar ratio of phytate: $Z$ Zn less than 10 showed adequate availability of $\mathrm{Zn}$ and problems were encountered when the value was greater than 15 . Values obtained here are compatible with results recorded for lupin seeds (Trugo et al., 1993).

\section{CONCLUSION}

This research shows that millipede is rich in protein and mineral contents and contains phytate, which may not inhibit $Z n$ availability. This sample may prove to be good ingredient that can be used in well-balanced livestock feeds.

\section{Further work.}

It is our intention to carry out further work on the effect of millipede supplementation of mixed concentrate rations on feed intake and growth rate in poultry birds.

\section{ACKNOWLEDGEMENT}

The authors are grateful to Mrs Oladimeji and Mrs Gabriel for the collection of the sample and Mr Akabude, P.O. for typing the manuscript.

\section{REFERENCES}

Abulude, F. O.. 2001. Mineral and phytate contents of vegetables grown in Nigeria and calculation of their phytate: $\mathrm{Zn}$ and Ca: Phytate molar ration. Adv . Food Sci. (CMTL) 23(1): 36-39.

Abulude, F. O., Akajagbor, C. and Dafiewhare, B. H. 2001. Distribution of trace minerals, phosphorus and phytate in some varieties of mushroom in Nigeria. Adv. Food Sci. (CMTL) (In press).

Adeyeye, E. I. 1996. Determination of major element in Illisha africana fish, associated water and soil sediments from scme fresh water pond. Bangladesh J. Sci. and Res. 31:171184.

Adeyeye, E. 1. 2000. Bio-concentration of macro and trace minerals in four prawns living in Lagos Lagoon. Pak. J. Sci. Ind. Res. 43(6):367-373.

Aduku, A. O. 1993. Tropical Feeding stuff Analysis Table. Department of Animal Science, Faculty of Agriculture, Ahmadu Bello University, Zaria, Nigeria.

Agbede, J. O. and Aletor, V. A. 1997. Haematology and biochemical aspects of feeding broiler-chickens conventional or underutilized protein sources. J. Appl. Tropical Agric. 2:57-62

AOAC 1990. Official Methods of Analysis, Association of Analytical Chemists, Washington, D. C., 15th edn

Hetzel, B. S, and Dun, J. T. 1989. The iodine deficiency disorder, their nature and prevention. Annu, Rev. Nutr. 9: 21-38.

Marcilese, N.A., Harms, R. H. Valesecchi, R. M. and Arrington,

- L. A. 1987. lodine uptake by ova of hens given excess iodine and effect upon ova development. J. Nutr. 94: 117 . 120.

Miller, S. A. and Harely, J. P. 1996. Zoology, 3rd edn, WCB/MCGrawHill Companies, Inc.USA. pg 383.

Oduguwa, O. O., Oduguwa, B. O., Onwuka, C. F. I. and Olajobi H. O. 1998. Antinutritional factors in foliages of $s o m$ e leguminous trees and shrubs Proceedings. $S$ i l $v$ e $r$ Anniversary Conference of NSAP, March $21 \quad 26$. Pp 339 340.

Olaofe, D., Arogundade, L. A., Adeyeye, E. I., Falusi, O. M. 1998. Composition and food properties of the variegated grasshopper, Zonocerus variegatus, Trop. Sci. 38: 233237. 
Payne, W. J. A and Wilson, R. T. 1999. An introduction to Animal Huabandry in the Tropics, 5th edn. Blackwell Sc. Ltd. Uk. p59.

Reddy, N. R., Sathe, S. K. and Salunkhe, D. K., 1982. Phytates in legumes and cereals. Adv. Food Res. 28: 192.

Roberts, M., Reiss, M. and Monger, G. 1996. Biology: Principles and Processes. Nelson Int. edn. Hong Kong, pp 122124.

Trugo, L. C., Donangelo, C. M., Duarte, Y. A. and Tavares, C. L. 1993. Phytic acid and selected mineral composition of seed from wild species and cultivated varieties of lupin. Food Chem. 47: 391394

Tull, A. 1990. Food and Nutrition, 2nd edn. Oxford University Press, Tokyo, pp 1235.

Vogel, A. 1989. Textbook of Qualitative Chemical Analysis, 5th edn., Longman Group Ltd. , London, pp 326701.

Wardlaw, G. M. 1999. Perspectives in nutrition, 4th edn. McGraw Hill Companies, USA 516521.

Wenlock, R. W., Buss, D. H., Moxon, R. E. and Bunton, N. G. 1982. Trace nutrients, 4 . lodine in British food. Br. J. Nutr. 47: 381390. 